\title{
Abuse of the Topic of Wealth by the Communist Regime: The Case of the Journal Charity Rudolf Svoboda
}

In spring 2013 a symposium called Pastoral care of the rich - points of departure, incentives, problems and possible solutions reflected from the point of view of biblical studies, history, ethics, psychology and pastoral theology took place at the Faculty of Theology, University of South Bohemia in České Budějovice.' This encounter made manifest that the topics of wealth, the rich and pastoral care of the rich are of utmost importance for contemporary church, especially in the sphere of Western civilisation. since these topics have so far received little attention in specialized discussions, the participants of the symposium have decided to place their results at the disposal of the wider public in scholarly papers. This paper is one of them.

The text is divided in two parts. The first part briefly and generally introduces some methodological limitations which researchers addressing the topics of wealth, the rich and pastoral care of the rich from the point of view of church history may encounter. It follows up on the above mentioned symposium and focuses on those points of departure, incentives, problems and possible solutions. It thus opens up space for the second part and contains among others an implicit explanation of the title of this paper. The second part of the paper deals with the very concrete issue of abuse of the topic of wealth in communist propaganda, of which in early 1950s the journal Charity became a vehicle.

\section{Methodological reflections, or else How to present a complex church-historical topic in the context of theological discussion}

When considering the relationship of theology and history, one can at present say that theologians in general accept the results of historical research and draw on it extensively. One of the tasks of history, which includes the field of church history, is to supply theologians with reliable resources and contexts for consideration (of course the relationship is to a certain extent reciprocal). ${ }^{2}$ With respect to the readers of this journal, which is not exclusively churchhistorical in profile, and also as a result of the discussions at the above mentioned symposium conducted especially with theologians of various specializations, I would like to clarify why it is problematic to present an overview of the topic of the rich or wealth in history or even pastoral care of the rich in history in the sense of "from-till" and offer a less debatable form of presentation - as indicated by the title of this paper. ${ }^{3}$

\footnotetext{
1 This symposium took place at the Faculty of Theology, University of South Bohemia in České Budějovice, on April 18, 2013.

2 I have discussed the place of church history within the framework of history and theology, its tasks and methods, generally as well as specifically, in several papers. See Rudolf SVOBODA, “Osvícenství, teologie a církevní historie”, in: Cornova, Revue České společnosti pro výzkum 18. století a Filozofické fakulty Univerzity Karlovy v Praze, vol. 1, no. 1/2011, pp. 11-26; Rudolf SVOBODA, “Boublíkova teologie dějin spásy. Myšlenky česko-ř́mského teologa jako inspirace pro církevní historii", in: Kateřina BRICHCÍNOVÁ, Karel SKALICKÝ, František ŠTĚCH, Tomáš VEBER (eds.), Teologie v utkání s pluralitou náboženství. Přínos Vladimíra Boublika v př́stupech a hodnoceních jeho žákủ, Kostelní Vydř́: Karmelitánské nakladatelství, 2009, pp. 69-76; Rudolf SVOBODA, “Theology and the Church History: Selected Questions towards their Mutual Relationship", in: Obnova činnosti košického kňažského seminára po roku 1989. Zborník prispevkov z medzinárodnej vedeckej konferencie Košice 6. októbra 2009, Prešov: Teologická fakulta KU v Ružomberoku - Vydavatelstvo Michala Vaška, 2009, pp. 58-60

3 At the above mentioned symposium I was confronted with the expectation that I will present a concise outline of "how it was in history".
} 
From a more general point of view one can say that if a researcher wants to tap the topics permeating the history of Christianity more deeply, she should not believe that by selecting views of the issue first from biblical texts, then from outstanding works of early Christian authors, from works of great mediaeval scholars, and from the enunciations of Councils and Popes up to the present the historical part of a theological issue will have been sufficiently covered. Placing the individual "enunciations" or "data" in chronological order without deeper historical context makes sense e.g. in Denzinger's compilation, if we are following the pronouncements of the Magisterium. ${ }^{4}$ But if we wanted to deal in such fashion with a historical topic - which e.g. pastoral care of the rich in church history certainly is (whereby I am not saying that it is not a theological topic as well) - we would obtain a rather narrow view, contributing little to deeper investigation of the topic. In other words such an overview would fail to convey an awareness of how profound differences there are between periods, centuries, places, doctrines and human generations. Differences sometimes so deep, incommensurate and hardly inter-connectable that if one tried to link the individual views of various eras or persons in a clear, well-arranged line, one may (as often happens) mix the proverbial "apples and oranges". Therefore though it may seem that the common denominator determined by the theological topic is perfectly sufficient, there is the fundamental risk of fabricating a history that never has been. Thereby I am not saying that history should be reserved to historians aware of all contexts and relationships (which is in fact impossible), merely reminding of the fact that history, as every other scholarly discipline, has certain rules, procedures and methods that must be observed and respected.

Another point that must not be overlooked is the fact that a historian's research must be based not only on primary and secondary literature, but especially on historical sources, which she rigorously and critically expounds - among others thanks to broad knowledge of the time, author, context of origin, etc. It is also necessary to expound the primary and secondary literature in a similarly critical fashion. Drawing conclusions from what one finds in secondary literature, or "composing" some comprehensive thematic lines from what is to be found in secondary literature - and even deducing (sic!) something from them - again almost certainly leads to distortions of the topic. ${ }^{5}$

4 I mean the compendium Heinrich DENZINGER, Enchyridion symbolorum definitionum et declarationum de rebus fidei et morum. Kompendium der Glaubensbekenntnisse und kirchlichen Lehrentscheidungen. Lateinisch - Deutsch. Freiburg im Breisgau: Herder Verlag, 1991.

5 I will now mention the example of a recent Czech, rather infelicitous procedure. The pastoral theologian Jakub Doležel of the Sts Cyril and Methodius Faculty of Theology has recently defended his doctoral thesis Theoretical Foundations of Church Social Work on the Background of Universal and Czech History of Charitable Work up to the Encyclical Deus caritas est, a part of which has even been published. See Jakub DOLEŽEL, Teoretické ukotvení církevní sociální práce na pozadí obecných a českých charitních dějin až po encykliku Deus caritas est, doctoral thesis, Cyrilometodějská teologická fakulta, Univerzita Palackého v Olomouci, Olomouc, 2011, supervisor Heinrich Pompey; further see Jakub DOLEŽEL, Církevní sociální práce na pozadi encykliky Deus caritas est, Olomouc: Univerzita Palackého v Olomouci, 2012.

In the second chapter of his doctoral thesis Doležel compiled an overview of the historical tradition of charitable practice of the church with emphasis on the Czech tradition. See ch. 2 called The Historical Tradition of Charitable Practice of the Church in Our Country, pp. 54-203. The subchapters are called Church social work as the topic of historical research, A brief outline of the universal history of church social work and Key moments of church social work in our country. Although the topic is not identical with the topic of wealth and the rich in church history, it is fairly close in content - one can easily find in Doležel's text the main points of how the church in its tradition and in works of its outstanding personalities viewed the rich and wealth in the course of time, i.e., since antiquity almost up to the present. It is not my intention to criticise the author, especially since the focus of his work was elsewhere, but his effort at a historical overview - contrived only on the basis of primary and especially secondary literature - illustrates that a non-historian should be careful not to set sail to unknown waters.

But Doležel did not confine himself to the historical overview, since in the partial summaries in subchapters 2.1, 2.2 and 2.3, as well as in the overall summary of chapter 2 (pp. 199-203) he attempts to identify "models of charitable work". See Jakub DOLEŽEL, Teoretické ukotvení církevní sociální práce.

I permit myself to claim that without correctly conducted historical investigation Doležel's conclusions have little value.

But in order not to do injustice to Doležel I must say that in another of his publications he manifests awareness of the limitations of his research, as he has shown e.g. in Jakub DOLEŽEL, "Církevní sociální práce jako téma historického bádání", in: Spravedlnost a služba IV, ed. Dita PALAŠČÁKOVÁ, Olomouc: CARITAS-VOŠ sociální Olomouc, 2010, pp. 63-76, where he introduced the view of charitable work in Willibald Ladenbauer's Das sociale Wirken der katholischen Kirche in der Diöcese Budweis (Wien, 1899) to the academic public. 
One might object that a person of sufficient erudition aware of the above mentioned differences may be capable of elaborating an overview of a topic extending through church history honourably and in depth. Perhaps so, but in fact this has so far been achieved in only a few rare cases. ${ }^{6}$ In this context I would like to refer to discussions which have been going on within the community of Czech church historians and theologians for already some years and follow up on similar debates abroad. The outcomes of these discussions are available to the public in the books Ecumenical Church Historiography $(2003)^{7}$ and Essays on the Nature of Church History (2012). ${ }^{8}$ Both contain contributions by the historians Jiři Hanuš and František X. Halas, the theologians Pavel Ambros and Jaroslav Vokoun, among others. Overall one can say that the two books unambiguously show that attempting to contrive general overviews in church history is pointless. In other words: it is impossible to "make" a fully complex and exhaustive church history, because earlier or later the author will meet with difficulties that she will not be able to overcome herself. These result not only from the very complexity of knowing the individual epochs, but also from the fact that there are different historical schools or conceptions of history determined e.g. by the author's confessional (non-)affiliation. Analogically all these claims hold for the present problem of wealth, the rich or the narrower issue of pastoral care of the rich.

I believe that if ten church historians were to address the present topics, each of them would come up with a different elaboration. That would be due not only to different perceptions of some periods of church history as well as specific church-historical or history-theological topics resulting (as already mentioned) from the possible differences in confessional orientation or other ideological grounding, but also to the fact that none of them can be an expert in all the two thousand years of Christian history. Of course, every church historian should be more then well-versed in it, as well as in general history, history of theology, history of culture, etc., but most are focused more narrowly on a specific part - just as a doctor knows well the whole human body and the foundations of all medical specializations, but for her degree she selects a particular specialization in which she then pursues perfection throughout her professional career. It would certainly turn out that the various epochs were covered in different depth: in some the researcher would be able to draw on previous results thanks to extensive interest in the period and prior historical and theological research, in others she will have to start practically from the scratch. In any case I believe that discussion of church historians dealing with the present topics should precede further interdisciplinary discussion or - if necessary run parallel to it.

There are situations in which it is worthwhile to do broad historical overviews even for such special topics as wealth and the rich in church history or pastoral care of the rich in history, e.g. when instructing students of Christian social and charitable work or those attending a course of practical theology. A general overview may also allow one to successfully indicate the number of cul-desacs in research work - which is not a bad way to facilitate first acquaintance with the topic or to design one's contribution at a symposium where there are colleagues from other theological or related fields or other listeners for whom a too narrowly focused contribution might not be welcome. In other words: although such method of addressing the issue is unsuitable for indepth treatment, in some situations it is necessary to acquire (or impart) general insight. I would therefore like to remind the readers that they may find basic general information on the topics

\footnotetext{
6 In the 20the century e.g. by a representative of the French school Annales Fernand Braudelovis by means of the conception "longue durée". 7 Jiří HANUŠ (ed.), Ekumenické církevní dějepisectví, Dějiny, analýzy, perspektivy, Brno: CDK, 2003. Worth reading is especially the introductory study by Berndt Jaspert to which the other authors then directly or indirectly respond.

8 Jiři HANUŠ (ed.), Eseje o povaze církevních dějin, Brno: CDK, 2012. The book to a certain extent evaluates the results of the discussion since the publishing of Ekumenické církeoní déjepisectoí, i.e., in about 10 years.
} 
not only in the already mentioned Doležel's work, ${ }^{9}$ but also in the works of primarily foreign authors, e.g. Herbert Haslinger, Gottfried Hammann and Markus Lehner. ${ }^{10}$ It is therefore obvious that if the reader were to look for information on wealth, the rich or pastoral care of the rich in the context of church history, she should consult works of authors dealing with history of pastoral care, as well as Christian social and charitable work. The topics are treated especially in connection with discussion of poverty and the poor - the topics are inseparable and closely interconnected.

The above considerations allow us to draw a conclusion: It is better if the author addresses - though in a partial manner and from the limited point of view of her specialization a less extensive topic, which she more precisely defines in terms of time, location, etc., then if she strives to contrive a general overview, which for fundamental reasons can never be fully general or exhaustive. Of course, addressing a partial issue also has its rules and pitfalls. The researcher must be aware of the limits determined by her own person as well as the very topic she intends to address - and openly acknowledge them to the reader. Such treatment of the topic may then become a serious contribution to further discussion. This is how the present study should be perceived.

\section{Abuse of the topic of wealth in the journal Charity}

\section{The Catholic Church as an ideological enemy of the Communist Party}

The gradual taking over of power by communists in post-war Czechoslovakia has already been covered quite extensively. Nonetheless, the topic has by far not been exhausted, whether as to content or as to the necessity of constant reminder - especially to members of the youngest generation who perceive the period as very distant and can hardly imagine the difficult situation of those whose religious or political orientation challenged the rising totalitarian regime. The fact that the communists took power gradually - beginning with the successful elections in 1946, through the February coup in 1948, to the subsequent strengthening of positions in the previously democratic state accompanied by ever more severe persecution of opponents - must incessantly be repeated.

It is well known that the Communist Party considered the Catholic Church, in number the most important representative of Christian communities in Czechoslovakia at the time, to be one of its main ideological enemies. It is therefore no wonder that especially after February 1948 the Catholic Church came under ever greater pressure, part of which were also direct and indirect attacks by state power, as part of the above mentioned process of strengthening positions and further taking over of power. A major role was played by the fight to gain control of institutions operated by the Catholic Church. By means of these the state power sought to win over some Catholics. An ideal vehicle of this intention appeared to be selected "Catholic" newspapers, journals and other press items, which the communists gained control of - having first banned publication of the truly Catholic ones. Partial facts related to this have

\footnotetext{
9 Doležel provides an up-to-date bibliography of Czech and foreign authors close to the topic. See Jakub DolEžEL, Teoretické ukotvení církevní sociální práce.

10 Herbert HASLINGER, Diakonie. Grundlagen für die soziale Arbeit der Kirche, Paderborn-Munchen-Wien-Zürich: Ferdinand Schöningh, 2009; Gottfried HAMMANN, Die Geschichte der christlichen Diakonie. Praktizierte Nächstenliebe von Antike bis zur Reformationszeit, Göttingen, 2003; Markus LEHNER, Caritas: Die Soziale Arbeit der Kirche, Freiburg: Lambertus, 1997.

For basic orientation the following works are also of interest: Herbert KRIMM (ed.), Quellen zur Geschichte der Diakonie. 3 Bd., Stuttgart, 1960-67; Rosario MESSINA, Dějiny charitativní činnosti, Kostelní Vydří: Karmelitánské nakladatelství, 2005.

An acclaimed overview of the rich in the church or pastoral care of the rich is not yet available.
} 
been presented in studies by Karel Kaplan, ${ }^{11}$ Václav Vaško, ${ }^{12}$ editors Jan Paulas and Jaroslav Šebek, ${ }^{13}$ and Martin Weis. ${ }^{14}$

\section{The journal Charity in 1946 - 1951}

One such authorized journal was Charity. Since the transformations of the journal are described in detail by another contemporary study, ${ }_{15}^{15}$ I will only present a brief summary: Charity was published since 1946, at first as a biweekly subtitled journal for social and health work. It was published by the Catholic Charity. ${ }^{16}$ In the first two years of its existence it was a Catholic journal in ideology and content, acquainting its readers with the social and charitable activities of the Catholic Church in post-war Czechoslovakia and abroad. It was directed by clergy loyal to the Catholic Church. ${ }^{17}$ When after the February coup the communists aimed to penetrate church structures with the help of sympathisers from among the clergy and use them to their ends, ${ }^{18}$ there very soon occurred interventions in the leadership of Catholic Charity. In April 1948 the so-called National Administration in the Central Committee of the Confederation of Catholic Charity was introduced. This administration consisted of clergy collaborating with the new regime: Josef František Fiala, Josef Klouček and Josef Plojhar. Following the instructions of the Communist Party this new leadership sought to appoint their own people to the institutions operated by Charity. The subsequent sharp protests of bishops against the restriction of church rights to engage in charitable activity had only limited effect: ${ }^{19}$ the Communist Party did not manage to get its people to the head of all church charitable institutions in Czechoslovakia, but in the leadership of Charity itself there remained people loyal to the new regime - Eduard Oliva, Jan Mára and Josef František Fiala. ${ }^{20}$

Changes in the leadership of the Catholic Charity affected the journal of the same name, published - as said above - by this institution. Although in 1948 it retained political neutrality as far as content was concerned, i.e., it discussed topics corresponding to its profile, the freedom did not last long: at the beginning of January 1949 publishing all Roman Catholic journals was terminated except the local Polish Wobranu pravdy and official bulletins of the individual dioceses - Acta curiae, the Catholic Weekly and the journal Charity. ${ }^{21}$ It was to be published in thirty thousand copies as a weekly ${ }^{22}$ devoted to social care as well as religious and church

11 Karel KAPLAN, Stát a církev v Československu v letech 1948 - 1953, Brno: Nakladatelství Doplněk, 1993.

12 Václav VAŠKO, Neumlčená, Kronika katolické církve v Československu po druhé světové válce, sv. 1, Praha: Zvon, 1990.

13 Jan PAULAS - Jaroslav ŠEBEK (ed.), Katolické noviny 1949-1989, Katolický týdeník, Praha: Katolický týdeník, 2009.

14 Martin WEIS, “Katolická církev ve světle Věstníku katolického duchovenstva”, Studia theologica 13, no. 1 [43] (2011): 80-98.

15 Rudolf SVOBODA - Jan HENDRYCH, “Časopis Charita a jeho proměny v letech 1946-1951”, Studia theologica 15, no. 4 (2013): 35-46.

16 More precisely it was published by the Central Committee of Confederations of Catholic Charity in Prague. See the masthead of the historically first issue of the journal: Charita, časopis pro sociální a zdravotní práci (further Charita) 1, no. 1 (1946). Cf. also VAŠKO, Neumlčená, vol. 1, Praha: Zvon, 1990, p. 189. Manners of using the name Catholic Charity or Central Committee of Confederation of Catholic Charity may be found e.g. in the above mentioned studies by Václav Vašek, Karel Kaplan and Martin Weis. Since the manner is already established, I will adhere to it in this paper.

17 Cf. SVOBODA - HENDRYCH, Časopis Charita, p. 36-37.

18 In order to investigate this topic the reader may - apart from the above and below mentioned books by Václav Vašek and Karel Kaplan also make use of the study by the Slovak historian Róbert Letz of the University of Bratislava. See Róbert LETZ, "Postavenie Katolické církvi v Československu v rokoch 1948-1989”, in Kř́ž pod rudou hvězdou, ed. Martin WEIS, Rudolf SVOBODA, České Budějovice: Jih, 2009, pp. 42-77, esp. 51-61.

19 Cf. Václav VAŠKO, Neumlčená, Kronika katolické církve v Československu po druhé světové válce, vol. 2, Praha: Zvon, 1990, pp. 46-47; SVOBODA - HENDRYCH, Časopis Charita, pp. 37-38.

20 All three became members of the pro-regime state "Catholic Action", founded in June 1949. The state "Catholic Action", its plans as well as reaction of bishops is described in detail in VAŠKO, Neumlčená, vol. 2, Praha: Zvon, 1990, pp. 67-78. For short biographies of these three men see SVOBODA - HENDRYCH, Časopis Charita, pp. 38-40.

21 How massive and fundamental the impact was is illustrated by the fact that in early 1948133 church and religious periodicals were being published in Czechoslovakia. Their activity was gradually constrained. The above mentioned ban concluded the process. Cf. Vojtěch NOVOTNÝ, Teologie ve stínu. Prolegomena k dějinám české katolické teologie druhé poloviny 20. století, Praha: Univerzita Karlova v Praze, Nakladatelství Karolinum, 2007, pp. 97-98.

22 The decision to publish Charity as a weekly was never carried through, in the following years it was published as a monthly. 
life. The editor-in-chief was to be Josef František Fiala. ${ }^{23}$ In other words the journal Charity was to become a powerful weapon of the Communist Party in the above mentioned fight for the loyalty of the Catholic public. ${ }^{24}$

Since then the pages of the journal came to be covered with proletarian and so-called peace issues, highlighting the role of the Soviet Union as liberator and warrant of peace. The writers took pains to show the similarity between communist ideals and the teaching of Jesus. As changes in state church policy occurred in $1949,{ }^{25}$ the contents of the journal changed, it was being more intensively used for communist propaganda. At the turn of 1949 and 1950 last changes in the editorial board took place, it came under the leadership of determined communists - and the contents of the journal changed even more. While up to that time church and charitable topics were predominant in the journal, only some articles were more communist than socialChristian in content and communist propaganda was to be found "between lines", now the journal became an unambiguous vehicle of communism. ${ }^{26}$ This reflected the church-political reality in communist Czechoslovakia in those years, rightly considered the toughest. ${ }^{27}$

In 1951 - i.e., in the last year of publication - the journal stood fully in service of the regime: the main topic was no longer assisting others but peace, endangered by Western capitalists, the articles are full of admiration for the Soviet Union, Stalin, the Communist Party and Gottwald. The decision to terminate its publication must be viewed in the context of state interventions against the Catholic Church in the previous three years. ${ }^{28}$ The Catholic Charity which published the journal as an institution became more or less a mere "union organization" for loyal representatives of the Catholic Church. It provided for holidays of clergy and engaged in production and sale of devotional articles. Places of internment of bothersome clergy also existed under the label of Catholic Charity. ${ }^{29}$

\section{The topic of wealth in the journal and its abuse}

In the pre-February issues of the journal Charity, and up until the state took control of Catholic Charity in April 1948, there is no explicit talk of wealth or the rich, but it is evident that the editors' aim was to show readers what is being done for the needy and in what ways others are taking part in assisting them in the difficult post-war times - most certainly with an intention

23 See Appendix 3 “Adjustment of church publications for 1949” in KAPLAN, Stát a církev, pp. 288-289; NOVOTNÝ, Teologie ve stínu, p. 99. The breadth of Czech and Slovak Catholic publications before 1948 is described in detail by Václav Vaško. See VAŠKO, Neumlčená, vol. 1, pp. 188-192.

24 The struggle is revealed by the Minutes of the meeting of the wider directorate of the Central Committee of the Communist Party of Czechoslovakia on April 25 1949. Cf. KAPLAN, Stát a církev, p. 351; SVOBODA - HENDRYCH, Časopis Charita, pp. 38-41.

25 One of the results of these changes was the internment of the Prague archbishop Josef Beran in June 1949 - shortly afterwards almost all diocesan bishops were in internment, then the so-called church laws were passed in autumn of the same year, by which the church came under strict control of the state. At the same time massive persecution was being prepared, the brutality of State Security was eliciting first deaths among the clergy. The State Office for Church Matters was created, as well as positions of church secretaries who were to monitor all religious activity. Their origination is described by Martin Weis in the paper Martin WEIS, "Okres na Jihu. Sonda do práce okresních církevních tajemníků ve světle archivních dokumentů jihočeského regionu", Studia theologica 13, no. 3 [45] (2011): 89-91.

26 The Catholic Newspaper wrote in a very similar fashion at the time. See PAULAS - ŠEBEK, Katolické noviny 1949-1989, pp. 10-39; SVOBODA - HENDRYCH, Časopis Charita, pp. 31-42.

27 At this very time the prosecutions of high church dignitaries were begun, the activity of all male and female religious orders was severely limited, cloisters and monasteries were confiscated and members interned. A large number of priests were also imprisoned. See e.g. VAŠKO, Neumlčená, vol. 2, pp. 109ff. The issue is discussed in detail in KAPLAN, Stát a církev, pp. 111ff; SVOBODA - HENDRYCH, Časopis Charita, pp. 42-43.

28 Vojtěch Novotný who has presented the procedure of the dissolution of Catholic press since 1948 in detail concludes in similar context that the communists' goal was first to abuse selected periodicals and then dissolve them. See NOVOTNÝ, Teologie ve stínu, p. 101, in broader context pp. 97-101.

29 See Martin WEIS, “Nebezpečný svatý Jan Nepomuk Neumann”, Studia theologica 12, no. 2 [40] (2010): 20-34, esp. note 10; Edita MENDELOVÁ, “Perzekuce ženských řeholí v r. 1950”, in Stát a církev v roce 1950, ed. Jiř́i HANUŠ, Jan STŘÍBRNÝ, Brno: CDK, 2000, pp. 84-85; Jindřich Zdeněk CHAROUZ, "Internační tábor Želiv", in: Stát a církev v roce 1950, ed. Jiří HANUŠ, Jan STŘÍBRNÝ, Brno: CDK, 2000, pp. 68-83, esp. pp. 73-78; VAŠKO, Neumlčená, vol. 2, pp. 190-191; SVOBODA - HENDRYCH, Časopis Charita, pp. 43-45. 
to inspire those who could help. The journal calls on all people of good will to join in the effort, it views charitable work as the common task of all - especially the faithful. It in no way juxtaposes the rich and the poor. Quite on the contrary, almost all issues highlight the exemplar practice of those who have helped as well as those who are grateful for the help. One could say that "rich" is not only one who has money, but also one who devotes his abilities and time to a good cause. In this sense the journal can definitely be viewed as specific means of pastoral care of the rich, i.e., those who help people who have not been as lucky in life.

It was similar in the second half of 1948 and in 1949: the topic of wealth is virtually not present, the journal engaged in the topics and changed in the fashion described above - i.e., Charity was not serving its original purpose anymore and was becoming a vehicle of communist propaganda.

Only in 1950, i.e., after radical changes in the editorial board, did wealth become one of the most frequent topics in Charity. In the ten issues published in that year it always occurs in close connection with religious issues. In general one can say that wealth is sharply criticized, as well as its owners - the rich, who are identified with capitalism, bourgeoisie, aristocracy and church hierarchy, in other words with the enemies of communism.

The writers of articles, sometimes anonymous or signed with initials, present the topic of wealth to the readers as a theological problem - they most commonly support their arguments with biblical texts, from which they derive unambiguous moral condemnations. The reasoning proceeds in all articles in a very similar fashion: Christianity proper is one in which the poor man comes first - just as in communism. Between the lines one can therefore read that a true Christian is a communist. Then the practice of the rich, who are viewed as bad Christians and at the same time enemies of communism, is condemned.

When arguing against wealth and the rich great Christian personages are often used. Here the article by Josef Vlastimil "Woe to you who are rich" must be cited. ${ }^{30}$ There the author paints a picture of the poverty, hunger and unemployment of many people in the world of Western cities, where the rich only take interest in their property and the poor employees cringe in shanties without help. He claims that in these cities many poor are dying in poverty, while their richer co-patriots are holding magnificent banquets in grand hotels - while the American army is murdering women and children in Korea. Then he presents a number of claims to show what Jesus himself thought of property and at the same time prove that Jesus was the first socialist: he unambiguously told the rich young man that if he wants to be perfect he must sell his property and give it to the poor; he further said that those who accumulate property will hardly enter God's Kingdom - as well as those who rely on their property. He preached poverty in the Sermon on the Mount. He allegedly constantly indicated that much property hinders salvation: "That is how we must understand his words, roaring in the souls of the rich: "Woe to you who are rich!" (Luke 6:24). As if he were saying, "Woe to you who light-heartedly watch your workers who have hardly a piece of bread to eat, you reduce their incomes and feast yourselves!" 31 The author mentions that Jesus did not condemn property honestly acquired, he even kept company with some well-to-do people - i.e., he did not condemn the rich because they were rich - but because they did not help the poor. Christ proclaimed love of one's neighbour to be the main foundation of his Kingdom. Love of one's neighbour is therefore to be the motor of social sensitivity and acting according to the Gospel. Only that will bring the rich to justly

30 Cf. Josef VLASTIMIL, “Běda vám, bohatí”, Charita 5, no. 8 (1950): 5-6.

31 Ibid., p. 5. 
reward the work of their neighbours. Then comes the claim that the church in the past did not honour Christ's precepts and forgot about loving one's neighbour - although the precept of loving the other is still valid. Then comes an "update", which is already pure propaganda: "In holes and huts there are crammed in the West or in the colonies unemployed wretches with no health care in rags, for a piece of bread accompanied by invectives and contempt, without protection and compassion of those to whom human lives should be of more value than sacks filled with dollars. But the exploiters dare to hide behind the Gospel of Christ as behind a screen. How good is life in our republic! There are no unemployed, no hungry, no ragged figures.... And who are we to thank? Only God and our workers. It is their achievement and the achievement of our government, who takes wise care of them. Work joyfully, reap joyfully, live joyfully, those are the slogans of our times. Let the Soviet Union be illustrious examplar to us all." ${ }^{22}$ The conclusion is similarly telling: "Together we have considered what Christ deemed of property. We have learnt that Christ's teaching in no way opposes the present social order. Quite on the contrary, it supports it." ${ }^{33}$

Another author, Pavel Martin, presents Jesus and the Apostles as workers. He quotes the Epistle of James exhorting against the rich - especially against those who withhold the deserved pay of workers. ${ }^{34}$

Elsewhere on the occasion of Advent Josef Ambrož speaks of the mission of Jesus Christ to liberate humanity from spiritual and moral poverty: "Magnificent palaces, statues, paintings, books by great poets - all that was merely a grandiose set decoration for the drama of exploitation of man by man ... the imposing figures of the famous poets and philosophers of the times were merely propagandistic instruments of political and economic oppression." 35 Jesus preached the equality and unanimity of all persons and peoples and fought for the poor, and therefore is exemplar for us. ${ }^{36}$

In the last issue of 1950 the discussion of "What Jesus thought of wealth", which had been going on throughout the year, culminates in the article "Holy night, silent night..." with a beautiful illustration of the manger. Having colourfully depicted Jesus' birth the anonymous author wrote: "Who were those distinguished by God and allowed to see the Saviour? They were poor shepherds! Looking after the fat herds of the rich, they often did not even have enough to feed their families for their labour... Born for us, for us... For the future Christian world, and therefore also for us, a champion of simple human rights and just order was born. It was HE who so clearly said "Sooner a camel will pass through a needle ear, than a single rich man through heaven's gate..." 37

John the Baptist was also presented as a campaigner against the rich. ${ }^{38}$ Elsewhere Josef Vlastimil uses the figure of St Adalbert, shown as someone who has learnt the "...weakness of life principles founded on wealth and power derived from wealth and titles." 39 Although he was bishop and nobleman, he allegedly became an exemplar son of the Czech people: he could make a living by working with his own hands, he did not let himself be beguiled by the magnificence and favour of the court and stood up for the people. The author even has him say "Do not believe the hypocritical promises of capitalist society, but follow me, Adalbert, my way of truth leading towards Slavonic East." 40

\footnotetext{
32 Ibid., pp. 5-6.

33 Ibid., p. 6.

34 Cf. Pavel MARTIN, “Práce je požehnáním”, Charita 5, no. 4 (1950): 18.

35 Josef AMBROŽ, “Advent a jeho poslání", Charita 5, no. 9 (1950): 4-5.

36 Ibid.

37 “Svatá noc, tichá noc...", Charita 5, no. 10 (1950): 4-5.

38 M. Hc. "Osobnost svatého Jana Křtitele", Charita 5, no. 6 (1950): 12.

39 Josef VLASTIMIL, “Cesta svatého Vojtěcha”, Charita 5, no. 4 (1950): 6-7.

40 Ibid., p. 7.
} 
Wealth was also discussed in the context of emphasizing so-called peace activities. Exhortation to peace was placed in connection with those who want war: the greedy, insatiable capitalists. ${ }^{41}$ The cruelty of the rich is shown e.g. on the example of the "terrible" conditions in American maternal hospitals, as compared to Czechoslovak ones: American hospitals just pump mothers and their families for money, they will not take care of a woman in need because they have no interest in an ordinary human, i.e., they only take care of the rich. In Czechoslovakia, on the other hand, everything is free, the aim is the health of the mother and the child. ${ }^{42}$ Elsewhere one can find the claim that the rich - the capitalists and the bourgeois - were never interested in the health of the people, since taking care of the needy would be expensive. At the forefront there is again the state which takes care of its poor. ${ }^{43}$

The topic of wealth is also mentioned in connection with the clergy: the article "Christians and work" paints repulsive pictures of lazy priests in offices and friars in cloisters engaging in repasts and revelling in their "voluminous bodies", who in wealth and without work live at the expense of others. The anonymous author of the text admonishes the clergy to go "to the Lord's vineyard", to work for the Kingdom of God - he therefore unconditionally rejects monastic life. ${ }^{44}$ When elsewhere Brothers of Charity in Prague are praised for selflessly taking care of the sick and dying for years "...when the rich forgot about them and scorned them", their way of caring is nonetheless viewed as a relict of the past, because the contemporary state takes much better care of whoever needs it. ${ }^{45}$

In his article "Roman Catholic priests fighting for peace" Alexandr Horák underlines not only the necessity for the clergy to cooperate with the government on the path to socialism, but speaks of the Divine purpose at Creation, which is "bonum commune", the common good. On the basis of that the author criticizes those who live at the expense of others and acquire property by chance, stratagem, avarice, inheritance, or primogeniture. He also criticizes the hierarchical order of the church which did not reward poor clergy (classified as workers!) according to their work, unlike the current state of affairs when clergy are rewarded by the state according to their merits. ${ }^{46}$ In the article "We need priests" Eduard Oliva directly links life in riches and low priestly vocations. ${ }^{47}$

It remains to be said that in the last year of publication the journal moved thematically towards emphasizing peace, admiration for the Soviet Union and proclamation of loyalty to the Communist Party. Religious issues played a marginal part, the focus was especially on health and political topics. ${ }^{48}$ Criticism of wealth virtually disappeared from the journal pages. ${ }^{49}$ It is quite logical: the phase when communists were trying to secure the loyalty of some Christian faithful by attempting to show them that communism is compatible with Christianity was over. The fight against the church was deemed to be practically won and it was possible to gradually proceed to the next phase of planned dissolution.

41 Cf. "Mír zárukou št'astné budoucnosti", Charita 5, no. 5 (1950): 19. The article was written according to a speech by J. Plojhar.

42 Cf. Anežka CHMELÍKOVÁ, “U nich a u nás”, Charita 5, no. 7 (1950): 15.

43 Cf. Karel MENŠíK, “Lid má právo na zdraví", Charita 5, no. 3 (1950): 16; Pavel MARTIN, “Nový pohled na nemocnici Milosrdných bratří v Praze", ibid., p. 19.

44 Cf. XY, “Křest́ané a práce”, Charita 5, no. 6 (1950): 6.

45 Cf. Pavel MARTIN, “Nový pohled na nemocnici Milosrdných bratří v Praze”, Charita 5, no. 3 (1950): 19-20, at 19.

46 Cf. Alexandr HORÁK, “Římskokatoličtía kněží v boji za mír”, Charita 5, no. 8 (1950): 9; in similar spirit runs the article František TRIPSKÝ,

"Rok církevních zákonů", Charita 5, no. 10 (1950): 15.

47 Cf. Eduard OLIVA, "Potřebujeme kněze", Charita 5, no. 8 (1950): 11-12.

48 Cf. SVOBODA - HENDRYCH, Časopis Charita, pp. 43-45.

49 Hints are also to be found in Eduard OLIVA, "Katolický kněz v čele hnutí obránců míru”, Charita 6, no. 1 (1951): 13-14, where the author speaks of unjust peace which the capitalists are trying to impose on the surrounding world, a peace founded on thousands of dead and on slaves suffering under the yoke of colonialism. 


\section{A few concluding words}

The journal Charity is significant as specific example and witness of the gradual dissolution of church activities by the communist regime after the February coup. It shows in a partial way how church structures were gradually permeated by communist sympathizers and subsequently used for communist purposes. For some time the journal served as a vehicle for communist propaganda. Its dissolution was the logical outcome of the ideological fight between the Catholic Church and Christianity as such and the Communist Party.

In fact, the question of abusing the topic of wealth in the journal Charity is a great paradox, since the topic was being addressed in a journal whose primary aim was to care for the needy. Priests serving the communist regime were using Christian topics to help the Communist Party defeat the Catholic Church (sometimes perhaps even without being fully aware of it) - and in this way the topics of wealth and the rich were abused as well.

It is sad that from the point of view of the collaborating priests on the editorial board of the journal as well as those writing the articles the propaganda was "pastoral care" of a kind, though horribly perverted. Their way of accomplishing pastoral care is so politicized, ideologically manipulated, simplifying, and conceived in black and white that if the historical context were not so grave, some of those priests" "exclamations" might be taken as fairly humorous. In their hands the fundamental topic of helping the poor became in 1950 a criticism of the rich who were mostly identified with ideological enemies: capitalism, the bourgeoisie, church hierarchy, the USA. Outstanding personages of Christian history, especially Jesus himself, were abused in the fight of the East against the West, communism against capitalism, the poor against the rich. Biblical reasoning, quite torn out of context of course, became an instrument of political struggle. The authors of the texts did all that with the intention of persuading the readers that communism and Christianity go hand in hand and at the same time show that the rich West is anti-Christian, therefore anti-communist and amoral.

\section{Abuse of the Topic of Wealth by the Communist Regime: The Case of the Journal Charity}

Abstract In its methodological part, the study first contributes to the current debate on the theological topics of the rich, wealth and pastoral care of the rich. It shows the basic methodological limitations a researcher may encounter while exploring these topics. In particular, it points out the problematic nature of the concept of historical overview in the context of current specialist discussions in the churchhistorical scholarly community. Subsequently, the study deals with the issue of abusing the topic of wealth by communist propaganda, of which the journal Charity (published from 1946 to 1951) became a vehicle in the early fifties. The paper shows the dark side of thinking about the rich and wealth: i.e., the abuse of this topic for political propaganda. The Communist Party viewed the Catholic Church as its ideological enemy. Soon after taking control of Czechoslovakia in February 1948 it banned most Catholic newspapers and magazines. Those which were still being published - the journal Charity among them - came under the control of people collaborating with the communists. Since 1949 the journal was used mainly for communist propaganda because in the interest of peaceful takeover and consolidation of power the communists wanted to get especially ordinary believers on their side. With the help of priests appointed to the governing body they used Biblical arguments and important figures in Christian history - including Jesus - to depict an ideological struggle of the East against the West, communism against capitalism - and also the poor against the rich. The topic of wealth became a powerful weapon of the ideological struggle in 1950.

Key words Charity, wealth, communism, Church, propaganda 